\title{
Induction of Cytotoxicity and Oxidative Stress of Dextran Coated Ferrite Nanoparticles (DFNPs) on A549 Cell Lines
}

\author{
Reshma VG and Mohanan PV* \\ Department of toxicology, Sree Chitra Tirunal Institute for Medical Sciences and Technology, India
}

Submission: October 06, 2016; Published: November 04, 2016

*Corresponding author: Mohanan PV, Toxicology Division, Biomedical Technology Wing, Sree Chitra Tirunal Institute for Medical Sciences and Technology, Kerala, India, Tel: 91-471-2520266; Fax: 91-471-2341814; Email: mohanpv10@gmail.com; mohanpv@sctimst.ac.in

\begin{abstract}
Super paramagnetic iron oxide nanoparticles have wide range of biomedical applications such as cellular and molecular imaging, site specific drug delivery etc. In the present study, in-house synthesized and characterized nano-size $(<25 \mathrm{~nm})$ dextran coated ferrite nanoparticles (DFNPs) was subjected to evaluate the cytotoxic potential by using tetrazolium salts MTT (3-(4,5-Dimethylthiazol-2-yl)-2,5diphenyltetrazolium bromide using A549 cell lines (human lung carcinoma cell lines), a model of type 2 human alveolar epithelial cells. Similarly, the effects of DFNPs on oxidative stress (reduced glutathione, Glutathione reductase, glutathione peroxidase, superoxide dismutase and lipid peroxidase) using mice lung homogenate were also investigated. Results of the study pointed out that there was a slight fluctuation in antioxidant enzyme activity and lipid peroxidation, and was not significant when compared to control values. DFNPs did not show cytotoxicity up to a concentration of $100 \mu \mathrm{g} / \mathrm{ml}$. Hence, the present study can be concluded that the in-house synthesized DFNPs were non-cytotoxic and promising their use for biomedical applications.
\end{abstract}

Keywords: Nanoparticles; Antioxidants; In vitro assays; Cytotoxicity; Genotoxicity; Biomedical

Abbreviations: DFNPs: Dextran Coated Ferrite Nanoparticles; MRI: Magnetic Resonance Imaging; ROS: Reactive Oxygen Species; DMEM: Dulbecco's Modified Eagles Medium; FBS: Fetal Bovine Serum; MTT: 3-(4,5-Dimethylthiazol-2-yl)-2,5-diphenyltetrazolium Bromide; TBA: Thiobarbituric Acid; GSH: Reduced Glutathione; TCA: Trichloroacetic Acid; DTNB: 5,5'-Dithiobis (2-Nitrobenzoic Acid); GSSG: Oxidized Glutathione; EDTA: Ethylene Diamine Tetra Acetic Acid; DTPA: Diethylene Triamine Penta-Acetic Acid; CPCSEA: Committee for the Purpose of Control and Supervision of Experimental Animals; LPO: Lipid Peroxidation Assay; GR: Glutathione reductase; GPx: Glutathione Peroxidase; SOD: Superoxide dismutase assay; MDA: Malondialdehyde; TBARS: Thiobarbituric Acid Reactive Substances; NADPH: Nicotinamide Adenine Dinucleotide Phosphate

\section{Introduction}

Nanoparticles are generally $1-100 \mathrm{~nm}$ scale small sized particles, have unique magnetic, optical, thermal, mechanical, electrical, electron configuration density characteristics and have a wide range of applications in medicine, electronics and energy production. They have ample applications for commercial purposes like opacifiers, semiconductors, catalysts, fillers, cosmetics and microelectronics. As a result of emerging growth of nanotechnology, large amount of fabrication of nanomaterials are possible in such a way that doped with noble metals (palladium, platinum and ruthenium) they can be used in various biomedical applications [1]. Super paramagnetic iron oxide nanoparticles are good diagnostic agents [2] and they are favorable site specific drug delivery systems owing to their capacity of targeting drugs by using external magnetic guidance [3].

Cellular labeling (in vivo macrophage activity) and targeting, separation and purification of cells, tissue repair, hyperthermia, magnetic resonance imaging (MRI), magnetofection, etc. are the applications of ferrite nanoparticles [4]. Early and specific detection of lung metastasis was done by high-resolution hyperpolarized 3He MRI using iron oxide nanoparticles functionalized with cancer binding ligands [5]. Surface modification of nanoparticles has multiple purposes [6]. It increases nanoparticles stability and biocompatibility, 
prevents agglomeration and loss of magnetism, minimizes the possibility of immunorejection. Commonly used surface coating materials of iron nanoparticles are PEG, Silica, Carboxydextran and polyethylene imine [7]. In this study, coating of ferrite nanoparticles done with dextran. Dextran is a branched polysaccharide, enhances their blood circulation time and stabilizes the colloidal solution [8,9]. Dextran coating can be quite stable in tissue environment because they are resistant to enzymatic degradation [10].

As potential application of ferrite nanoparticles increases, concerns over their potential effects on human health also increases and hence toxicological analysis is very essential. The same in-house synthesized ferrite nanoparticles were found to be nontoxic on dermal exposure and liver samples of both the in vitro and in vivo studies [11]. Also it didn't show any toxicity when exposed to rats orally [12]. Currently very little information is known about the toxicity concern of these nanoparticles on lung cells. The present study was carried out on a human tumor cell line, A549, a well advised model of type 2 human alveolar epithelial cells [13] which are regularly exposed to nanoparticles upon inhalation.

Previous nano toxicological studies showed that Iron oxide nanoparticles cause production of increased level of reactive oxygen species (ROS) [14-17]. High level of ROS production will cause damage of cells by lipid peroxidation, protein oxidation and mitochondrial damage. It also lead to the DNA disruption, gene transcription modulation and can then trigger a cascade of $\mathrm{Ca}^{2+}$ - dependent signaling mechanisms resulting in a decline in physiological functions and cell apoptosis/death [18]. Based on the above literature, it was decided to evaluate the cytotoxicity and induction of oxidative stress of in-house synthesized DFNPs on A549 cell lines and lung homogenate isolated from exposed and unexposed (control) mice.

\section{Materials and Methods}

Dextran coated Ferrite Nanoparticles (SCTIMST, India), Dulbecco's Modified Eagles Medium (DMEM), Trypsin EDTA, antibiotic and antimycotic solution (10,000 units/ml penicillin, $10,000 \mu \mathrm{g} / \mathrm{ml}$ of streptomycin and $25 \mu \mathrm{g} / \mathrm{ml}$ of Fungizone ${ }^{\circledR}$ Antimycotic), Fetal Bovine Serum (FBS), $\mathrm{Ca}^{2+}, \mathrm{Mg}^{2+}$ free phosphate buffered saline, were purchased from Gibco (Grand Island, NY, USA). Sodium bicarbonate (Sigma Chemicals Co. Ltd. St. Louis, MO,USA), 3-(4,5-Dimethylthiazol-2-yl)-2,5-diphenyltetrazolium bromide (MTT), Sodium carbonate, Copper sulphate, Sodium potassium tartarate, Folin's phenol reagents, Thiobarbituric acid (TBA), Sodium dodecyl sulphate, Acetic acid, Reduced glutathione(GSH), Trichloro acetic acid (TCA), 5,5'-Dithiobis(2nitrobenzoic acid) DTNB, Oxidized glutathione (GSSG), Sodium azide, Hydrogen peroxide $\left(\mathrm{H}_{2} \mathrm{O}_{2}\right.$ ) (Sigma Chemicals Co. Ltd. St. Louis, MO, USA), Ethylene diamine tetra Acetic acid (EDTA) (Merck, Germany), Tri sodium citrate, Diethylene triamine penta-acetic acid (DTPA) and physiological saline (Parenteral
Drugs Ltd. India) were used. All the chemicals and reagents used were of analytical grade.

\section{Animal husbandry and experimental animals}

All animals were handled humanely, without making pain or distress and with due care for their welfare. The care and management of the animals will comply with the regulations of the Committee for the Purpose of Control and Supervision of Experimental Animals (CPCSEA), Govt. of India. All the animal experiments were carried out after prior approval from Institutional Animal Ethics Committee and in accordance with approved institutional protocol.

\section{Synthesis and characterization of DFNPs}

Synthesis and characterization of DFNPs was carried out previously by our team [11]. TEM image of DFNPs given in (Figure 1).

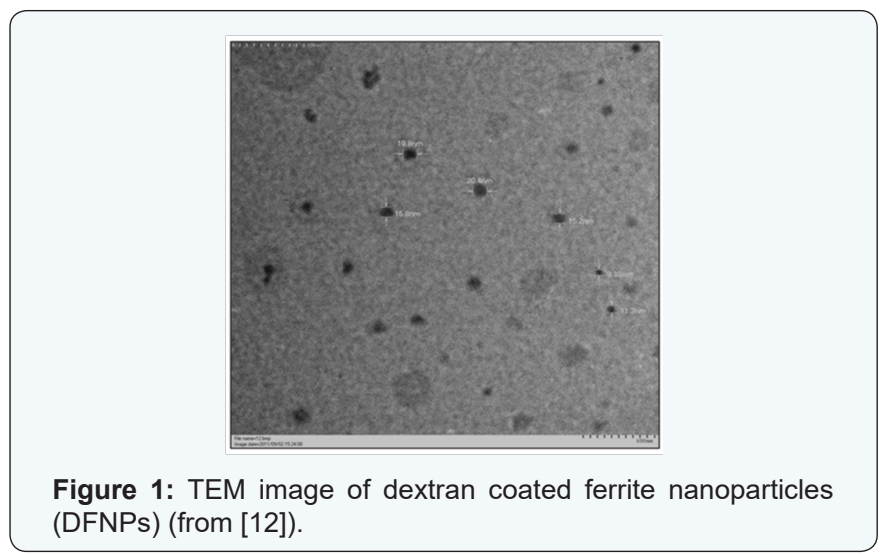

\section{Culture of A549 Cell lines}

A549, human lung adenocarcinoma epithelial cell line, were cultured in DMEM, high glucose medium supplemented with $10 \%$ FBS, $1 \%$ antibiotic-antimycotic solution. Cells at $80-85 \%$ confluence were used for the entire study.

\section{In Vitro cytotoxicity assay using MTT}

In vitro cytotoxicity was evaluated by MTT assay [19]. In brief, the A549 cells were seeded at an initial density of 1 X10 4 cells/well. After $24 \mathrm{~h}$ of seeding, the cells were treated with DFNPs [11], 100, 600, 800, $1000 \mu \mathrm{g} / \mathrm{ml}$ ) for $24 \mathrm{~h}, 48 \mathrm{~h}$ and $72 \mathrm{~h}$ at $37 \pm 1^{\circ} \mathrm{C}$. Cells were then incubated with $100 \mu \mathrm{l} /$ well MTT for $3-4 \mathrm{~h}$ in dark. The formazan crystals formed by the intracellular reduction of tetrazolium salt which are impermeable to the cell membrane accumulated within the healthy cells. These crystals were solubilized by adding $100 \mu \mathrm{L}$ DSO and incubated for 15 minutes in dark. Absorbance was measured at $540 \mathrm{~nm}$ using a multiwall plate reader (Bio-Tek Instruments Inc). The relative cell viability (\%) with respect to negative control was calculated.

\section{Oxidative stress}

I. Preparation of lung homogenate: In vitro studies on oxidative stress were carried out in lungs tissue homogenate 
isolated from exposed and unexposed Swiss albino mice (25$30 \mathrm{~g}$ body weight). Experimental animals were sacrificed by cervical dislocation. Aseptically collected lungs were placed in an ice bath immediately after washed in normal saline. $10 \%$ of lungs tissue homogenate was prepared in phosphate buffer (0.1 M, pH 7.4) using an ice-chilled glass homogenizing vessel in a rotor stator homogenizer at $900 \mathrm{rpm}$. Further, the lungs tissue homogenate was incubated with increasing concentration $(12.5,25,50$ and $100 \mu \mathrm{g} / \mathrm{ml})$ of DFNPs for $3 \mathrm{~h}$ independently at $37^{\circ} \mathrm{C}$ in shaking water bath and centrifuged at $3500 \mathrm{rpm}$ for $10 \mathrm{~min}$ at $4^{\circ} \mathrm{C}$ in a refrigerated centrifuge. The supernatant was kept in an ice bath and was used for the estimation of total protein, antioxidants assays like lipid peroxidation assay (LPO), Reduced glutathione (GSH), Glutathione reductase (GR), Glutathione peroxidase (GPx), Superoxide dismutase assay (SOD) using standard protocols with slight modifications.

II. Total Protein: Total proteins in the lung tissue homogenate were analyzed with Folin-phenol reagent by Lowry's method [20]. Total protein was spectrophotometrically measured at $660 \mathrm{~nm}$.

III. Lipid peroxidation (LPO): The extent of lipid peroxidation in the lung tissue homogenate of mice exposed to DFNPs was determined as the concentration of malondialdehyde (MDA) produced by the thiobarbituric acid reactive substances (TBARS), as described by OkadoMatsumoto and Fridovich [21]. The amount of MDA formed was spectrophotometrically measured at $532 \mathrm{~nm}$.

IV. Glutathione reductase (GR): As described by Mize and Langdon, GR activity of DFNPs treated lung tissue homogenate was determined by measuring the reduction of oxidized glutathione (GSSG) in the presence of Nicotinamide adenine dinucleotide phosphate (NADPH). The rate of NADPH oxidation to NADP+, along with decrease in absorbance at $340 \mathrm{~nm}$ was monitored spectrophotometrically. One GR unit is defined as the reduction of one $\mu \mathrm{M}$ of GSSG per minute at $25^{\circ} \mathrm{C}$ and $\mathrm{pH}$ 7.6.

V. Reduced glutathione (GSH): The level of GSH in DFNPs exposed experiment was determined by the method of Moron et al. [22] with slight modifications. DTNB (5,5'-dithiobis-(2nitrobenzoic acid) or Ellman's reagent reacts with GSH to form a spectrophotometrically detectable product at $412 \mathrm{~nm}$. The change in absorbance at $412 \mathrm{~nm}$ is a linear function of the GSH concentration in the reaction mixture. Reaction of GSH with DTNB gives a compound that absorbs at $412 \mathrm{~nm}$. The amount of GSH was expressed as nmol/ mg protein.

VI. Glutathione peroxidase (GPx): GPx activity of DFNPs exposed assay was estimated by the method described by Rotruck et al. [23]. The remaining GSH after the enzyme catalyzed reaction was complexed with DTNB, which is absorbed at maximum wavelength of $412 \mathrm{~nm}$. Enzyme activity was expressed as $\mu \mathrm{g}$ of GSH consumed /min/mg protein.

VII. Superoxide dismutase assay (SOD): Superoxide dismutase assay was done in lung tissue homogenate (exposed to DFNPs) using modified pyrogallol auto oxidation method and was spectrophotometrically measured at $420 \mathrm{~nm}$ [24].

VIII. Statistical analysis: Triplicate experiments were carried out. The values were expressed as mean \pm SD. Student's ' $\mathrm{t}$ ' test was used for statistical analysis. $P$ value of $<0.05$ was considered statistically significant.

\section{Results}

\section{Cytotoxicity}

Concentration dependent toxicity was observed by MTT assay. The percentage mitochondrial activity was more or less similar to that of negative control after $24 \mathrm{~h}$ of incubation up to $800 \mu \mathrm{g} / \mathrm{ml}$ of DFNPs. Cell viability was decreased below $80 \%$ at $1000 \mu \mathrm{g} / \mathrm{ml}$. There was no change in cell viability $(600 \mu \mathrm{g} / \mathrm{ml})$ as compared with the negative control at the end of $48 \mathrm{~h}$. The cell viability was decreased to $50 \%$, when the concentrations of DFNPs were 800 and $1000 \mu \mathrm{g} / \mathrm{ml}$. It was also noted that the cells were similar to that of control at $72 \mathrm{~h}$ for $100 \mu \mathrm{g} / \mathrm{ml}$ treatments, $60 \%$ for $600 \mu \mathrm{g} / \mathrm{ml}$ and $20 \%$ at 800 and $1000 \mu \mathrm{g} / \mathrm{ml}$ of DFNPs (Figure 2).

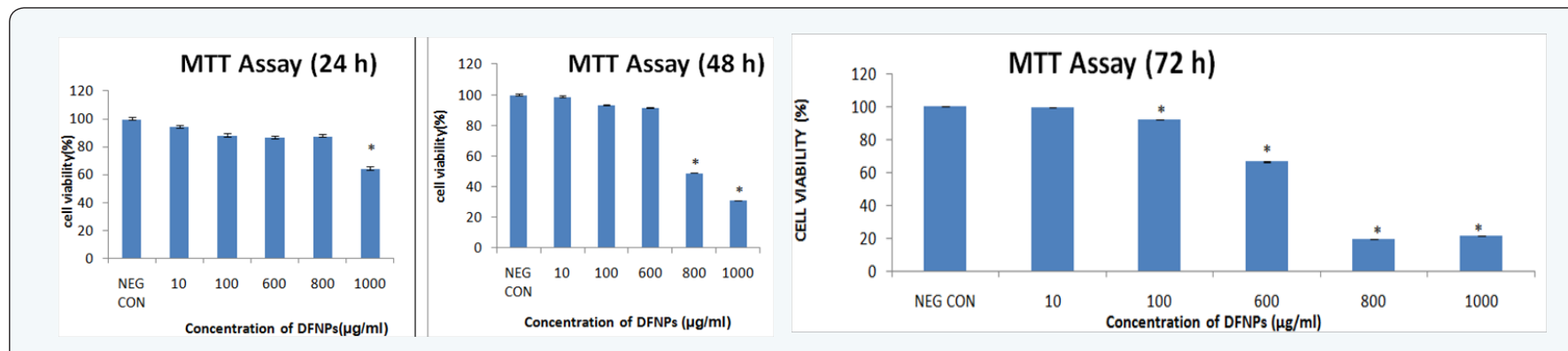

Figure 2: MTT assay showing cytotoxic effect of DFNPs on A549 cells after $24,48,72 \mathrm{hr}$ of incubation. Cells were incubated with different concentrations of DFNPs. Measured mitochondrial activity represented as percentage with respect to control. The data expressed as mean \pm SD. Asterisk above columns denotes statistically significant difference when compared to the control group $(P<0.05)$. 


\section{Antioxidant assay}

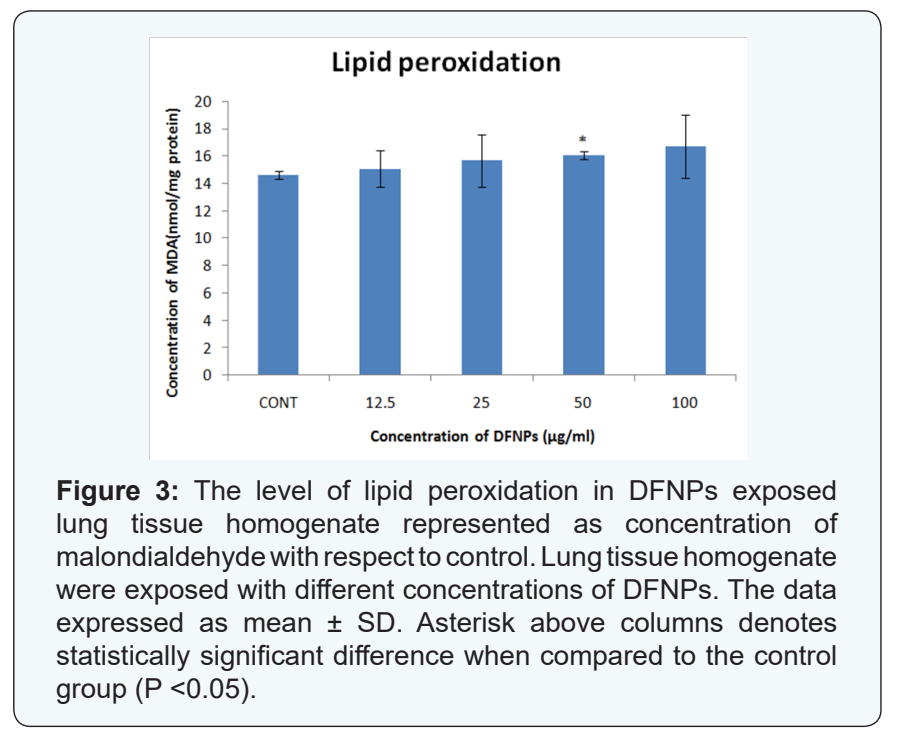

a. Lipid peroxidation (LPO): The results of the lipid peroxidation are defined in the (Figure 3). The figure represents MDA production in the mice lungs homogenate (in vitro) incubated with the different concentrations of DFNPs $(12.5,25,50,100 \mu \mathrm{g} / \mathrm{ml})$. It was found that the level of lipid peroxidation slightly increased by the DFNPs at various concentrations $(12.5,25,50,100 \mu \mathrm{g} / \mathrm{ml})$ compared to control cells.

b. Glutathione reductase (GR): The activity of GR increased in a concentration dependent manner (12.5, 25 and up to $50 \mu \mathrm{g} / \mathrm{ml}$ of DFNPs) as compared with that of control $(0.473 \pm 0.014)$ as $0.513 \pm 0.111,0.546 \pm 0.025$, $0.581 \pm 0.042$ units $/ \mathrm{mg}$ protein respectively. But at a higher concentration of $100 \mu \mathrm{g} / \mathrm{ml}$, level of glutathione reductase $(0.416 \pm 0.007)$ is less than the control (Figure 4)

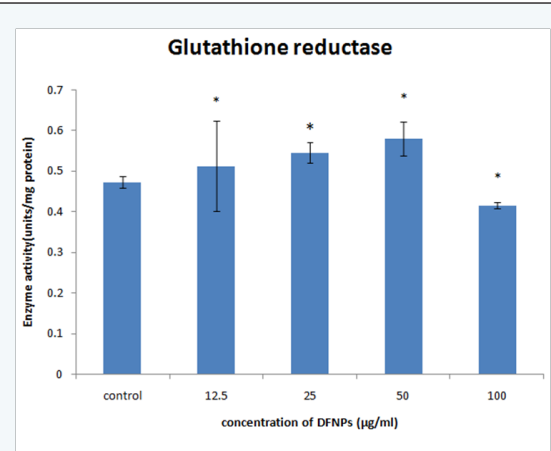

Figure 4: Glutathione reductase activity in DFNPs treated lung tissue homogenate. Lung tissue homogenate were exposed with different concentrations of DFNPs. The data expressed as mean \pm SD. Asterisk above columns denotes statistically significant difference when compared to the control group $(P<0.05)$.

c. Reduced glutathione (GSH): GSH level decreases as the concentration of DFNPs $(\mu \mathrm{g} / \mathrm{ml})$ increases as compared to control $(0.065 \pm 0.016)$. Level of GSH at concentrations of $12.5,25,50,100 \mu \mathrm{g} / \mathrm{ml}$ DFNPs are $0.043 \pm 0.014,0.038$ $\pm 0.016,0.031 \pm 0.008,0.018 \pm 0.008$ nanomole $/ \mathrm{mg}$ respectively (Figure 5). Level of GSH decreased by $4.7 \%$ at $100 \mu \mathrm{g} / \mathrm{ml}$ concentration of DFNPs.

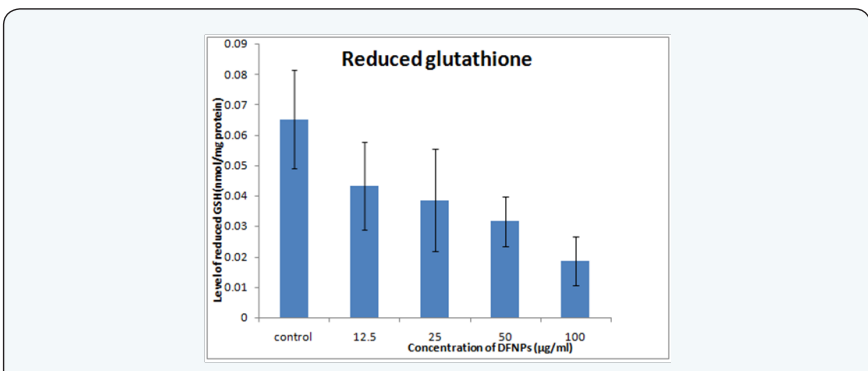

Figure 5: Reduced glutathione activity in DFNPs exposed lung tissue homogenate. Lung tissue homogenate were exposed with different concentrations of DFNPs. The data expressed as mean \pm SD.

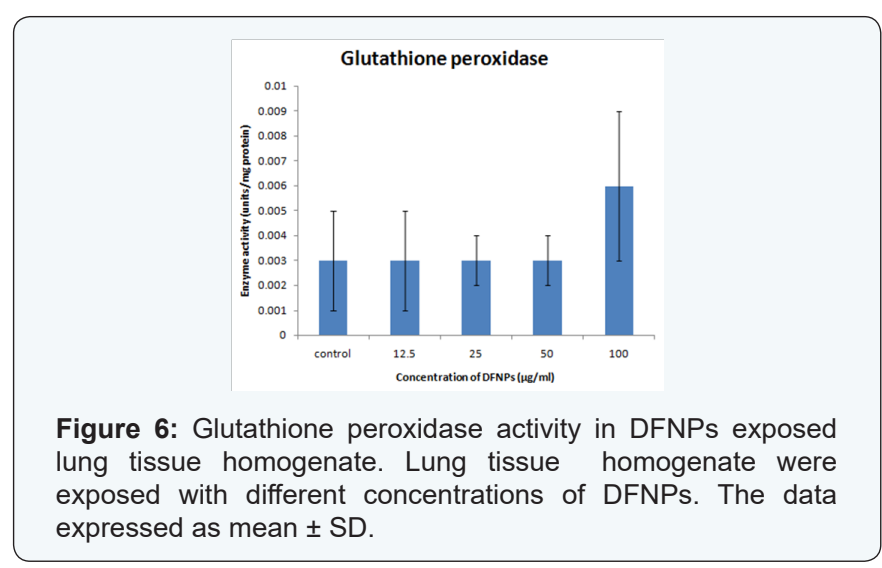

d. Glutathione peroxidase (GPx): Level of GPx increased only at high concentration of DFNPs $(100 \mu \mathrm{g} / \mathrm{ml})$ i.e. $0.006 \pm$ 0.003 units $/ \mathrm{mg}$ protein. In all other concentrations of DFNPs $(12.5,25,50 \mu \mathrm{g} / \mathrm{ml})$, no significant change in level of GPx $(0.003 \pm 0.002,0.003 \pm 0.001,0.003 \pm 0.001)$ in comparison with control $(0.003 \pm 0.002)$ (Figure 6).

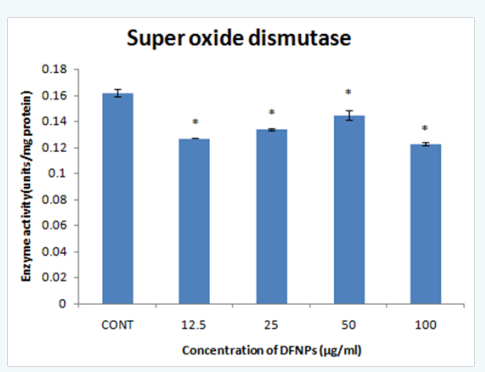

Figure 7: Superoxide dismutase activity in DFNPs exposed lung tissue homogenate. Lung tissue homogenate were exposed with different concentrations of DFNPs. The data expressed as mean \pm SD. Asterisk above columns denotes statistically significant difference when compared to the control group $(P<0.05)$. 
e. Superoxide dismutase assay (SOD): The production of SOD in lung homogenate of mice exposed to different concentrations of DFNPs is shown in (Figure 7). The level of SOD at different concentration $12.5,25,50,100 \mu \mathrm{g} / \mathrm{ml}$ are $0.127 \pm 5.7,0.134 \pm 0.001,0.145 \pm 0.004,0.123 \pm 0.001$ units/mg protein respectively. Level of SOD in control is $0.163 \pm 0.003$.

\section{Discussion}

Iron oxide nanoparticles have gained tremendous attention because of its broad biomedical application. Functionalized Iron oxide nanoparticles with cancer binding ligands can be used for targeting cancer cells. High-resolution hyperpolarized ${ }^{3} \mathrm{He}$ MRI could use for imaging [25]. Researchers, manufacturers and other end users are often exposed to nanoparticle either unintentionally or deliberately. Inhalation being the main mode of nanoparticle exposure and only little information is available about their pulmonary toxicity. Hence analysis of pulmonary toxicity at molecular level is very essential. The current study focused on analysis of in vitro cytotoxicity and antioxidant activity of in-house synthesized DFNPs towards A549 cells. Property of nanoparticles and its interaction with biological system mainly depends on many factors like its size, charge, surface coating and purity of the material. Hence characterization of nanoparticle must be carried out before evaluating their toxicity.

Physicochemical characterization of in-house synthesized DFNPs was carried out and from this study it was found that the synthesized nanoparticles were authentic with a size of less than $25 \mathrm{~nm}$ with effective coating of dextran [11]. Dextran, a branched complex of glucose is used for coating of ferrite nanoparticles. In this study, MTT assay was carried out on A549 lung epithelial cells to confirm cytotoxicity of different concentration of DFNPs for different time periods. MTT can enter the cell and passes into mitochondria where it is reduced to insoluble purple formazan products by succinate dehydrogenase. Since MTT can reduce only in metabolically active cells the level of activity is a measure of the viability of the cells. The cells are then solublized formazan crystals with an organic solvent and released from cells which is measured spectrophotometrically. Even though cells do not show marked reduction in cell viability up to $600 \mu \mathrm{g} / \mathrm{ml}$, a progressive reduction can be seen in a dose and time dependent manner.

Oxidative stress is one of the prominent mechanisms of nanoparticle toxicity which is due to the production of ROS. These highly reactive free radicals due to the presence of unpaired electrons in their outer most shell have crucial role in cell's life and death. ROS is produced as a result of normal metabolism and other physiological processes of cells. Its level increases above normal leads to several pathological conditions. However endogenous antioxidant system has main role in regulating the intracellular homeostasis. Loss of correlation between ROS generation level and antioxidant defense activity will lead to the cellular oxidative stress. This stress is overcome by antioxidant system, consists of three types i.e. primary, secondary and tertiary. Primary antioxidants prevent oxidants formation. E.g: ROS protective enzyme like Super oxide dismutase (SOD), GPx etc. Glutathione reductase is the secondary antioxidant enzyme.

Nucleic acids, proteins and lipids are the major cellular macromolecules which are badly affected by oxidative stress. Peroxidation of lipid is the most harmful, mainly due to a facile propagation of free radical reactions as part of lipid peroxidation. Lipid peroxidation is initiated by abstraction of hydrogen atom from the PUFA moiety of membrane phospholipids. Phospholipid hydroperoxides and fatty acid hydroperoxides are directly attacked by ROS. During lipid peroxidation, spontaneous cleavage of the fatty acid carbon chain will result in highly toxic pentane, ethane, $\alpha, \beta$ unsaturated fatty acids and aldehydes. Aldehydic secondary products like MDA and 4-HNE as a result of lipid peroxidation of $\omega 3$ and $\omega 6$ PUFA are accepted as markers for oxidative stress [26]. In the present study, it was found that there is a slight increase in lipid peroxidation in treated cells compared to control cells so that DFNPs do not produce ROS which is destruct the PUFA present in the plasma membrane.

Reduced glutathione (GSH) is an active ROS scavenger among the group [27] and is known as body's master antioxidant. Antioxidant defensive nature of GSH is mainly due to the presence of thiol group. Glutathione disulfide (GSSG) formed as a result of glutathione peroxidase activity on GSH. Glutathione reductase further reduces the formed GSSG to GSH in a NADPH dependent manner [28]. Result of the study indicated that GSH level decreased in small amount upon exposure of increasing concentration of DFNPs.GSH depletion in tissues lead to breakage of cellular defense against ROS and which may lead to peroxidative injury [29]. The level of Glutathione reductase increased slightly at $50 \mu \mathrm{g} / \mathrm{ml}$ and decreased at $100 \mu \mathrm{g} / \mathrm{ml}$ of DFNPs. Reduction in the level of Glutathione reductase at $100 \mu \mathrm{g} /$ $\mathrm{ml}$ of DFNPs is may be due to the particle aggregation because of the large concentration of particle. Cellular uptake is reduced as a result of decreased surface activity of large aggregate so that ROS production decreased.

Glutathione peroxidase enzyme protecting the body against oxidative stress by scavenging hydrogen and lipid peroxides. The result of the study suggests that there is no fluctuation in level of Glutathione peroxidase up to $50 \mu \mathrm{g} / \mathrm{ml}$ concentration of DFNPs. But at higher concentration $(100 \mu \mathrm{g} / \mathrm{ml})$, level of this enzyme increased, which may be due the presence of large amount of hydrogen and lipid peroxides under stress.

SOD is one of the main detoxifying enzymes present in all living cells. Main function of SOD is the destruction of free radical superoxide by converting it to peroxide. Catalase or GPx acts on peroxide for its further destruction. Low concentration of superoxide is regularly produced by aerobic respiration. Mainly three forms of SOD present in humans. Manganese containing SOD is primarily present in mitochondrial matrix and [30] 
copper/zinc-SOD present in cytosol and in lysosomes [31,32]. Extracellular SOD is also present. Decomposition of hydrogen peroxide or organic peroxides is catalyzed by glutathione peroxidase. The result of current study indicates that SOD level increases as concentration of DFNPs increases. But at higher concentration $(100 \mu \mathrm{g} / \mathrm{ml})$ SOD level found to be decreased. This may be due to depletion of enzyme. SOD may remain active until all necessary co factors will be available. Insignificant difference in the above antioxidant parameters implies that DFNPs may not be toxic at the dose of $100 \mu \mathrm{g} / \mathrm{ml}$.

\section{Conclusion}

The result of in vitro cytotoxicity study concluded that nano sized DFNPs $(<25 \mathrm{~nm})$ is non cytotoxic to A549 cells. No significant fluctuation is seen in the level of lipid peroxidation and antioxidant defense mechanism. Hence, the present study can be concluded that the in-house synthesized DFNPs were non-toxic at cellular level and promising their use for biomedical applications.

\section{Acknowledgment}

Authors are thankful to the Director and Head, Biomedical Technology Wing, Sree Chitra Tirunal Institute for Medical Sciences and Technology for providing the facilities to carry out the work.

\section{References}

1. Bertolucci E, Marracci M (2015) Chemical and Magnetic Properties Characterization of Magnetic Nanoparticles. IEEE 978-1-4799-6144-6.

2. Gupta AK, Gupta M (2005) Cytotoxicity suppression and cellular uptake enhancement of surface modified magnetic nanoparticles. Biomaterials 26(13): 1565-1573.

3. Mahmoudi M, Hosseinkhani H, Hosseinkhani M, Boutry S, Simchi A, et al. (2011) Magnetic resonance imaging tracking of stem cells in vivo using iron oxide nanoparticles as a tool for the advancement of clinical regenerative medicine. Chem Rev 111(2): 253-280.

4. Gupta AK, Gupta M (2005) Synthesis and surface engineering of iron oxide nanoparticles for biomedical applications. Biomaterials 26(18): 3995-4021.

5. Rosa T Branca, Zackary I Cleveland, Boma Fubara, Challa SSR Kumar, Robert R Maronpo, et al. (2010) Molecular MRI for sensitive and specific detection of lung metastases. PNAS 107(8): 3693-3697.

6. Kim JE, Shin JY, Cho MH (2012) Magnetic nanoparticles: An update of application for drug delivery and possible toxic effects. Arch Toxicol 86(5): 685-700.

7. Valdiglesias V, Kiliç G, Costa C, Fernández-Bertólez N, Pásaro E, et al (2015) Effect of Iron Oxide Nanoparticles: Cytotoxicity, Genotoxicity, Developmental toxicity, and neurotoxicity. Environmental and Molecular Mutagenesis 56(2): 125-148.

8. Berry CC, Curtis ASG (2003) Functionalisation of magnetic nanoparticles for applications in biomedicine. Journal of Physics D Applied Physics 36(13): 198-206.

9. Berry CC, Wells S, Charles S, Curtis AS (2003) Dextran and albumin derivatised iron oxide nanoparticles: influence on fibroblasts in vitro. Biomaterials 24(25): 4551-4557.
10. B Crepon, J Jozefonvicz, V Chytry, B Řihová, J Kopeček (1991) Enzymatic Degradation and Immunogenic Properties of Derivatized Dextrans. Biomaterials 12(6): 550-554.

11. Mohanan PV, Syama S, Sabareeswaran A, Sreekanth PJ, Varma HK (2014) Molecular toxicity of dextran coated ferrite nanoparticles after dermal exposure to Wistar rats. The Journal of Toxicology and Health 104: 406-422.

12. Syama S, Reshma SC, Leji B, Anju M, Sreekanth PJ, et al. (2014) Toxicity Evaluation of Dextran Coated Ferrite Nanomaterials After Acute Oral Exposure to Wistar Rats. J Allergy Ther 5: 166.

13. Corbière V, Dirix V, Norrenberg S, Cappello $M$, Remmelink $M$, et al. (2011) Phenotypic characteristics of human type II alveolar epithelial cells suitable for antigen presentation to T lymphocytes. Respir Res 12: 15.

14. Nel A, Xia T, Madler L, Li N (2006) Toxic potential of materials at the nanolevel. Science 311(5761): 622-627.

15. Klaus Unfried, Catrin Albrecht, Lars Oliver Klotz, Anna Von Mikecz, Susanne Grether-Beck, et al. (2007) Cellular responses to nanoparticles: Target structures and mechanisms. Nanotoxicology 1(1): 52-71.

16. Shubayev VI, Pisanic TR $2^{\text {nd }}$, Jin S (2009) Magnetic nanoparticles for theragnostics. Adv Drug Deliv Rev 61(6): 467-477.

17. Soenen SJ, De Cuyper M (2009) Assessing cytotoxicity of (iron oxide based) nanoparticles: An overview of different methods exemplified with cationic magnetoliposomes. Contrast Media Mol Imaging 4(5): 207-219.

18. Stroh A, Zimmer C, Gutzeit C, Jakstadt M, Marschinke F, et al. (2004) Iron oxide particles for molecular magnetic resonance imaging cause transient oxidative stress in rat macrophages. Free Radic Biol Med 36(8): 976-984.

19. Mosmann T (1983) Rapid colorimetric assay for cellular growth and survival: application to proliferation and cytotoxicity assays. J Immunol Methods 65(1-2): 55-63.

20. LOWRY OH, ROSEBROUGH NJ, FARR AL, RANDALL RJ (1951) Protein measurement with the Folin phenol reagent. J Biol Chem 193(1): 265275.

21. MATTILL HA (1947) Antioxidants. Annu Rev Biochem 16: 177-192.

22. Moron MS, Depierre JW, Mannervik B (1979) Levels of glutathione, glutathione reductase and glutathione $S$-transferase activities in rat lung and liver. Biochem Biophys Acta 582(1): 67-78.

23. Rotruck JT, Pope AL, Ganther HE, Swanson AB, Hafeman DG, et al. (1973) Biochemical role as a component of glutathione peroxidase. Science 179(4073): 588-590.

24. Marklund S, Marklund (1974) GInvolvement of the superoxide anion radical in the autoxidation of pyrogallol and a convenient assay for superoxide dismutase. Eur J Biochem 47(3): 469-474.

25. Fain S, Schiebler ML, McCormack DG, Parraga G (2010) Imaging of Lung Function using Hyperpolarized Helium-3 Magnetic Resonance Imaging: Review of Current and Emerging Translational Methods and Applications. J Magn Reson Imaging 32(6): 1398-1408.

26. Halliwell B, Gutteridge JM (1990) The antioxidants of human extracellular fluids. Arch Biochem Biophys 280(1): 1-8.

27. Dickinson DA, Forman HJ (2002) Cellular glutathione and thiols metabolism. Biochem Pharmacol 64(5-6): 1019-1026.

28. Ichikawa I, Kiyama S, Yoshioka T (1994) Renal antioxidant enzymes: their regulation and function. Kidney Int 45(1): 1-9.

29. Sies H, Akerboom TP (1984) Glutathione disulfide (GSSG) efflux from cells and tissues. Methods Enzymol 105: 445-451. 
30. Bannister JV, Bannister WH, Rotilio G (1987) Aspects of the structure, function, and applications of superoxide dismutase. CRC Crit Rev Biochem 22(2): 111-180.

31. Geller BL, Winge DR (1982) Rat liver Cu, Zn-superoxide dismutase subcellular location in lysosomes. J Biol Chem 257(15): 8945-8952.
32. Weisiger RA, Fridovich I (1973) Mitochondrial superoxide dismutase. Site of synthesis and intramitochondrial localization. J Biol Chem 248(13): 4793-4796.

Your next submission with JuniperPublishers will reach you the below assets

- Quality Editorial service

- Swift Peer Review

- Reprints availability

- E-prints Service

- Manuscript Podcast for convenient understanding

- Global attainment for your research

- Manuscript accessibility in different formats ( Pdf, E-pub, Full Text, Audio)

- Unceasing customer service

Track the below URL for one-step submission http://juniperpublishers.com/online-submission.php 